\title{
Effect of subsidies on fertilizer sale in Shrirampur and Nagar tahasil
}

\section{S.D. Varandal and A.S. Kshirsagar}

Received : 24.10.2018; Revised : 13.03.2019; Accepted : 25.03.2019

\begin{abstract}
We studied about effect of fertilizer subsidy on sale of fertilizer. This study was conducted between July 2018 to Sept. 2018 on the sample of 200 farmers selected on convenience from 12 villages of 2 talukas of Ahemadnagar district which are Shrirampur and Nagar. Primary data was collected by survey method on pretested semi-structured schedule and appropriate tools were used to analysis of data. Shrirampur taluka has good irrigation facilities as compared to Nagar taluka. 78 per cent farmers used solid fertilizer and 35 per cent farmers used water soluble fertilizer. Solid fertilizer has low prices because government provide subsidy on solid fertilizer and so that its sale is high. But in case of water soluble fertilizer, government does not provide any subsidy so that its price is high and its sale is low as compare to solid fertilizer. 41.5 per cent farmers think about fertilizer subsidy while buying of fertilizers. But 50 per cent famers buy product on the basis on price so that we can say that the sale of solid fertilizer is high than water soluble fertilizer.
\end{abstract}

KEY WORDS : Fertilizer, Subsidy, Solid fertilizer, Water soluble fertilizer, Price

How to cite this paper : Varandal, S.D. and Kshirsagar, A.S. (2019). Effect of subsidies on fertilizer sale in Shrirampur and Nagar tahasil. Internat. J. Com. \& Bus. Manage, 12(1) : 28-32, DOI: 10.15740/HAS/IJCBM/12.1/28-32. Copyright@ 2019: Hind Agri-Horticultural Society.

\section{MEMBERS OF THE RESEARCH FORUM}

Correspondence to:

S.D. Varandal, College of Agriculture Business Management, Loni (M.S.) India

E-mail: shreyasvarandal@gmail.com

Authors' affiliations:

A.S. Kshirsagar, College of Agriculture Business Management, Loni (M.S.) India

E-mail: ashishpravara@gmail.com 